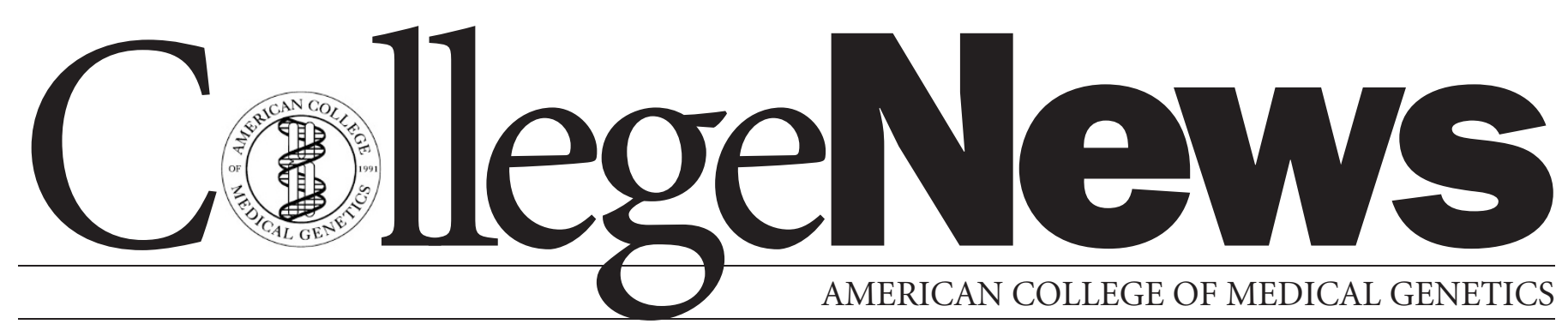

\title{
Did You Know...
}

- You can download an ACMG product order form from the ACMG website? To download, click on the "Products" tab from the ACMG homepage at www.acmg.net, then select "ACMG Products" from the drop down menu. Click the link to download and print your order form.

- That ACMG has reference materials available for download or review from the ACMG website? ACMG reference materials include: a patent primer from the Intellectual Property Subcommittee; valuable points to consider when preparing license agreements for patented genetic tests; a comprehensive review of genetic testing and Warfarin dosing; and ACMG's ACT Sheets and Confirmatory Algorithms. From the homepage, click on the "Resources" tab then select "References" from the drop-down menu.

- You can find lots of information on careers in genetics from the ACMG website? Click on the "Education" tab from the ACMG homepage then select "Careers in Genetics" from the drop down menu.

\section{ACMG Takes to the Air and Airwaves in May to Inform Public About Medical Genetics:}

As part of its mission, ACMG uses a variety of tools to increase the visibility and understanding of medical genetics and to inform and educate not only professionals, but also patients and the public. ACMG's newest outreach and public relations effort includes a radio program, $21^{\text {st }}$ Century Healthcare Forum which will run on all audio-equipped flights of American Airlines (approx. 29,000 flights) and Northwest Airlines (approx. 2,880 flights) in May 2008, and will reach a potential audience of 4.9 million people.

Bruce Korf, PhD, MD, FACMG, ACMG President-elect discusses ACMG's important work, medical genetics and its role in improving health in this high profile SkyRadio Network program. The $2 \mathbf{1}^{\text {st }}$ Century Healthcare Forum is an ongoing show dedicated to healthcare and its effect on you. Other recent topics on this program have included Heart Disease in Children, Achieving a World Without Alzheimer and New Developments in Stem Cell Research. Other guests have included President Jimmy Carter, former Secretary of State Madeleine Albright, Tommy Thompson and many major CEOs and dignitaries. 


\section{ACMG has undertaken a public relations and outreach campaign to inform and educate the public about medical genetics?}

ACMG has been included in such high profile media as:

- The New York Times

- US News \& World Report

- ABC.com

- Associated Press and Scripps News

- The Wall Street Journal

- USA Today

- The Washington Post

- Resident and Staff Physician

- Numerous network affiliates of ABC, NBC, CBS and Fox

- The International Herald Tribune

- Taipei Times

- High profile websites dedicated to genetics, medicine and science including ScienceDaily.com, RedOrbit.com. and MedicalNewsToday.com

- Trade and Industry Publications including Advance for Administrators of the Laboratory, Genetic Engineering \& Biotechnology News, Pharmacogenomics Reporter, GeneRef.com, NurseWeek, Medical Device Industry News, Clinical Lab Products, The Pink Sheet

and hundreds more, reaching millions of viewers and readers with news and information about medical genetics and health!

ACMG is Working Hard to Raise the Awareness, Visibility and Understanding of Our Profession.

Visit the Online Newsroom at www.ACMG.net to read ACMG News Releases and Media Statements.

\section{Mark your Calendars \\ Upcoming ACMG Annual Clinical Genetics Meetings}

March 25-29, 2009

Tampa Convention Center \& Marriott Waterside Hotel and Marina

Tampa, Florida 